\title{
Ratios of Cells With and Without Virulence Genes in Rhodococcus fascians Populations Correlate with Degrees of Symptom Development
}

\author{
Ekaterina V. Nikolaeva, Sook-Young Park, and Seogchan Kang, Department of Plant Pathology, Penn State Uni- \\ versity, University Park, PA 16802; and Tracey N. Olson and Seong H. Kim, Pennsylvania Department of Agricul- \\ ture, Harrisburg 17110
}

\begin{abstract}
Nikolaeva, E. V., Park, S.-Y., Kang, S., Olson, T. N., and Kim, S. H. 2009. Ratios of cells with and without virulence genes in Rhodococcus fascians populations correlate with degrees of symptom development. Plant Dis. 93:499-506.

Rhodococcus fascians, a gram-positive phytopathogenic bacterium, causes fasciation and leafy galls on a wide range of monocotyledonous and dicotyledonous plants for which it requires the plasmid-borne fas operon. Strains isolated from symptomatic plants over a 20-year-period exhibited a high degree of variability when their virulence was assessed on garden pea seedlings. Polymerase chain reaction amplification of the fas- 1 and fas $R$ virulence genes from randomly chosen single colonies showed that many strains consisted of two subpopulations, of which one had lost these genes. Inoculation of pea seedlings with mixtures of fas-1-positive and -negative cells that originated from the same strain demonstrated a strong correlation (Pearson's $r \geq$ 0.9205 ) between the proportion of cells in the inoculum carrying the fas- 1 gene and the severity of disease symptoms. The minimal concentration of fas-1-positive cells required for the development of small lateral shoots on pea seedlings was $2.5 \times 10^{4} \mathrm{CFU} / \mathrm{ml}(P \leq 0.008)$, while the overall suppression of main stem growth was observed at $2.5 \times 10^{5} \mathrm{CFU} / \mathrm{ml}(P \leq 0.019)$. These observations underline that care should be taken when the virulence of clinical $R$. fascians strains is evaluated.
\end{abstract}

Rhodococcus fascians (Tilford 1936) Goodfellow 1984, a gram-positive phytopathogenic bacterium (formerly Corynebacterium fascians), infects a wide range of monocotyledonous and dicotyledonous plants $(1,9,10,14,18,21,27)$ and induces disease symptoms such as leaf deformation, thickened hypocotyls, stunted growth, arrested root development, multiple shoot formation, and initiation of leafy galls. Disease severity is dependent on the host species and cultivar, plant age, site of infection, bacterial strain, and environmental or growth conditions (30). The disease is most often on bulb, floral, and greenhouse crops (18) and can affect significantly the commercial value of ornamentals by changes in morphology and reduced flower production (32).

$R$. fascians colonizes the surface and the interior of its hosts, and the induced hyperplasia represent a specific niche that can be exploited by the bacteria $(3,9,32)$. Leafy galls originate from proliferation of existing and newly induced meristems and consist of compact masses of meristematic tissue covered with small multiple shoots $(13,16)$. The hypothesis that abnormal

Corresponding author: S. H. Kim

E-mail: skim@state.pa.us

Accepted for publication 17 January 2009.

doi:10.1094/PDIS-93-5-0499

(C) 2009 The American Phytopathological Society growth in infected hosts is caused by disruption of hormone balance is supported by changed cytokinin $(8,26)$ and auxin $(29,30)$ levels in infected tissues and the presence of an isopentenyl transferase (ipt) gene (= fas1), which is involved in the synthesis of a cytokinin-like product and is required for virulence in $R$. fascians (4). In strain D188, three loci on the linear virulence plasmidfas, att, and hyp $(5,25)$ - and a chromosomal vic locus (31) have been shown to be necessary for symptom expression and bacterial survival in plants, respectively.

Pea bioassays have been widely used for virulence assessment of $R$. fascians strains $(12,15,20,26)$. However, susceptibility to infection is strongly dependent on the pea cultivar and the growth conditions, which may have contributed to variable and inconsistent results within and between different studies $(7,23)$. Given the increasing importance of $R$. fascians problems to the horticultural industry, we need to know more about the underlying reasons for this variability in virulence assays.

In this study, we investigated genotypic and phenotypic differences among $R$. fassue of several cultivated plant species between 1984 and 2005 and showed that the spontaneous loss of the fas genes in the bacterial populations causes virulence variation.

\section{MATERIALS AND METHODS}

Bacterial strains and growth conditions. In total, $89 R$. fascians strains were cians strains isolated from symptomatic tis- isolated by the authors from symptomatic samples of multiple greenhouse crop species, which had been submitted by plant inspectors of the Pennsylvania Department of Agriculture (PDA) between 1984 and 2005 (12,19; Table 1). For bacterial isolation, symptomatic tissues were washed with sterile water, finely chopped into small pieces, suspended for $1 \mathrm{~h}$ in $10 \mathrm{mM}$ sterile phosphate buffer ( $\mathrm{pH} 7.4)$, agitated briefly, and then streaked onto yeastdextrose-calcium carbonate (YDC) agar. After 4 to 5 days of incubation at room temperature $\left(23\right.$ to $\left.25^{\circ} \mathrm{C}\right)$, gram-positive, yellow-orange-tinged colonies were isolated for further characterization. For longterm storage, the selected single colonies were transferred to nutrient broth (Difco Laboratories, Detroit) and cultured on a shaker at $75 \mathrm{rpm}$ for $24 \mathrm{~h}$ at 23 to $25^{\circ} \mathrm{C}$. The cultures (four replications of each strain) were stored in nutrient broth containing $10 \%$ glycerol in 2.0-ml Nalgene Cryoware cryogenic vials (Nalge Nunc International, Rochester, NY) at $-80^{\circ} \mathrm{C}$. The reference strain used in this study was ATCC 12975 (American Type Culture Collection, Manassas, VA). R. fascians strains had previously been identified by cultural characteristics, gram tests, pea bioassays, or searches of the Biolog database (Biolog, Hayward, CA), and their taxonomic identity was confirmed by sequencing the $16 \mathrm{~S}$ ribosomal RNA (rRNA) gene.

Molecular characterization of strains. Genomic DNA from $R$. fascians cultures grown in YDC was extracted using the Bactozol kit (Molecular Research Center, Inc., Cincinnati, OH) according to the manufacturer's instructions. DNA Ladder I (GeneChoice, Frederick, MD) was used to estimate the concentration of the resulting genomic DNA samples. PCR amplifications of the plasmid-borne virulence genes fas- 1 and fas $R$, the chromosomal virulence gene vicA, and the internal transcribed spacer (ITS) region of rRNA genes were performed using a thermal cycler PTC-200 (MJ Research Inc., Hercules, CA). Additionally, a few representative virulent and avirulent strains were tested by PCR for the presence of four other genes (attA, $a t t R$, firl, and fir2) that are located at different parts of the same virulence plasmid in order to confirm the presence or absence of the whole virulence plasmid. The reaction mixture included $10 \mu \mathrm{M}$ each primer, 
FailSafe polymerase chain reaction (PCR) $2 \times$ Premix F (Epicentre, Madison, WI), 2 $\mathrm{U}$ of AmpliTaq polymerase (Applied Biosystems, Foster City, CA), and 1 to $2 \mathrm{ng}$ of DNA in a final volume of $25 \mu \mathrm{l}$. The primers used in this study are listed in Table 2, which includes both previously reported and newly designed primers. PCR products were analyzed by electrophoresis using $1.5 \%$ agarose gel and visualized with GelDok-It Imaging System (UVP, Upland, CA) after ethidium bromide staining.

Pea bioassay. The original replications of each frozen $R$. fascians strain collected in Pennsylvania from 1984 to 2005 were tested by pea bioassay in 2005 . For the inoculum preparation, individual $R$. fascians strains were grown for 3 days in sucrose asparagine thiamine (SAT) me- dium (26) in 50-ml flasks at room temperature $\left(23\right.$ to $\left.25^{\circ} \mathrm{C}\right)$ using an orbit incubator-shaker (Lab-line 3529, Melrose Park, IL). Prior to inoculation, each inoculum suspension was adjusted to $2.5 \times 10^{7}$ $\mathrm{CFU} / \mathrm{ml}$ (optical density of 0.18 at 600 nm) with SAT medium using a UV/VIS Spectrometer (Perkin-Elmer, Waltham, $\mathrm{MA})$. The actual CFU was confirmed by placing $5 \mu \mathrm{l}$ of serially diluted bacterial

Table 1. Genotypic and phenotypic characteristics of Rhodococcus fascians strains isolated from symptomatic ornamental plants in Pennsylvania greenhouses during 1984 to 2005

\begin{tabular}{|c|c|c|c|c|}
\hline \multirow[b]{2}{*}{ Group, year (strain no.) ${ }^{\mathrm{x}}$} & \multirow[b]{2}{*}{ Symptoms $(\%)^{\mathrm{y}}$} & \multicolumn{3}{|c|}{ Presence of target genes ${ }^{w}$} \\
\hline & & fas-1 & fas $R$ & ITS \\
\hline \multicolumn{5}{|l|}{ Group A } \\
\hline $\begin{array}{l}1984 \text { (Rf-01); } 1994 \text { (Rf-13); } 1995 \text { (Rf-23); } 1996 \text { (Rf-10, Rf-18); } 1997 \text { (Rf-61, Rf-68); } 2000 \text { (Rf-58); } \\
2002 \text { (Rf-36, Rf-39, Rf-43, Rf-47, Rf-49, Rf-50, Rf-73); } 2003 \text { (Rf-27, Rf-84); } 2004 \text { (Rf-93, Rf- }\end{array}$ & & & & \\
\hline 98); 2005 (Rf-99, Rf-106, Rf-107) & $100.0 \mathrm{a}$ & + & + & + \\
\hline $\begin{array}{l}1994 \text { (Rf-03, Rf-12); } 1996 \text { (Rf-17); } 2000 \text { (Rf-48); } 2001 \text { (Rf-32); } 2002 \text { (Rf-31, Rf-56); } 2003 \text { (Rf-87); } \\
2004 \text { (Rf-94) }\end{array}$ & $91.7-97.5 \mathrm{a}$ & + & + & + \\
\hline \multicolumn{5}{|l|}{ Group $\mathrm{B}^{\mathrm{z}}$} \\
\hline $\begin{array}{l}1994 \text { (Rf-08, Rf-09, Rf-75); } 1995 \text { (Rf-21); } 1997 \text { (Rf-67); } 1998 \text { (Rf-74*, Rf-81); } 1999 \text { (Rf-63, Rf- } \\
\text { 80); } 2000 \text { (Rf-26, Rf-60); } 2001 \text { (Rf-14, Rf-35*, Rf-37*); } 2002 \text { (Rf-38*); } 2003 \text { (Rf-71); } 2004 \text { (Rf- } \\
\text { 89, Rf-90, Rf-95, Rf-96, Rf-97); } 2005 \text { (Rf-102, Rf-104) }\end{array}$ & $0.0 \mathrm{f}$ & - & - & + \\
\hline 1944 (ATCC 12975); 1997 (Rf-66*, Rf-76*); 2002 (Rf-44*); 2003 (Rf-40*) & $5.0-15.0 \mathrm{f}$ & \pm & \pm & + \\
\hline \multicolumn{5}{|l|}{ Group C } \\
\hline $2000($ Rf-83) & $88.9 \mathrm{ab}$ & + & + & + \\
\hline $\begin{array}{l}1998 \text { (Rf-16); } 2000 \text { (Rf-28, Rf-59); } 2001 \text { (Rf-30); } 2002 \text { (Rf-15); } 2003 \text { (Rf-70); } 2004 \text { (Rf-105); } 2005 \\
\text { (Rf-103) }\end{array}$ & $85.7-87.5 \mathrm{a}-\mathrm{c}$ & + & + & + \\
\hline $\begin{array}{l}1996 \text { (Rf-20, Rf-25, Rf-24); } 1997 \text { (Rf-51); } 1998 \text { (Rf-34); } 1999 \text { (Rf-82); } 2002 \text { (Rf-05, Rf-52, Rf-54); } \\
2003 \text { (Rf-06, Rf-86) }\end{array}$ & $75.4-83.4 \mathrm{a}-\mathrm{d}$ & + & + & + \\
\hline 2003 (Rf-85); 2004 (Rf-92, Rf-91); 2005 (Rf-100, Rf-101) & $61.1-68.8 \mathrm{a}-\mathrm{d}$ & + & \pm & + \\
\hline 2002 (Rf-53, Rf-46) & $52.5-61.5 \mathrm{c}-\mathrm{e}$ & + & + & + \\
\hline 2002 (Rf-72) & $51.5 \mathrm{c}-\mathrm{e}$ & + & \pm & + \\
\hline 2001 (Rf-29); 1998 (Rf-79); 2002 (Rf-41) & $20.0-26.5$ ef & \pm & \pm & + \\
\hline
\end{tabular}

${ }^{w}$ The presence of plasmid-borne virulence genes fas- 1 and fas $R$ and the internal transcribed spacer (ITS) region of rRNA-encoding genes in individual strains was determined by polymerase chain reaction (PCR): $+=$ positive, $-=$ negative, and $\pm=$ faint band or inconsistent results. PCR was performed with approximately $1 \mathrm{ng}$ of bacterial genomic DNA as a template.

${ }^{x}$. fascians strains isolated from Pennsylvania Department of Agriculture (PDA) clinical samples and confirmed by sequencing. Usually, one isolate was collected and stored from each plant sample. However, two isolates with different cultural or virulence characteristics were stored from four PDA samples (Rf-21 and Rf-23, Rf-29 and Rf-30, Rf-53 and Rf-54, and Rf-72 and Rf-73).

${ }^{y}$ Symptom development reflects the percentage of pea seedlings (cv. Alaska) showing fasciation symptoms at 14 days post inoculation. Means followed by the same letters are not significantly different according to Student-Newman-Keuls Test $(\alpha=0.01)$, SAS analysis of variance procedure. Three independent inoculation assays (10 seedlings for each assay) were performed.

${ }^{z}$ Most of the strains included in group B were determined to be nonpathogenic when they were originally isolated and tested for their virulence. Strains marked with * were originally determined to be weakly pathogenic.

Table 2. Sequences of the primers used in this study

\begin{tabular}{|c|c|c|c|}
\hline Primers ${ }^{w}$ & Nucleotide sequences, $5^{\prime}$ to $3^{\prime}$ & Target, function of a target gene & Reference \\
\hline \multicolumn{4}{|c|}{ Chromosomal genes } \\
\hline ITS-38 R & TGCGGCTGGATCTCCTT & Bacterial internal transcribed spacer & 17 \\
\hline ITS-72 F & CCGGGTTTCCCCATTCGG & $\ldots$ & \\
\hline VicA-15F & GAAATCGAATAGGACCTTGG & vicA gene, putative malate synthase & $31^{\mathrm{x}}$ \\
\hline VicA-15R & ACTCGGTCACGAGGGAAC & $\ldots$ & $\ldots$ \\
\hline \multicolumn{4}{|c|}{ Plasmid-borne genes } \\
\hline fasR F & ATCAACGTCGACCTCGGAAT & fas $R$ gene, regulatory protein & $25^{\mathrm{x}}$ \\
\hline fasR R & GCACGGGTTACAGTCATT & $\ldots$ & $\ldots$ \\
\hline JPE R & CGGGATCCATATCGAACCGCCCTC & ipt (fas-1) gene, iso-pentenyltransferase & 23 \\
\hline JPE L & GGGAATTCCGACCGTATCCAGTGT & $\ldots$ & $\ldots$ \\
\hline fir $1-10 \mathrm{~F}$ & ATTCGTTACGGGATCGCTCGGATT & firl gene, fir 1 protein & $\ldots y^{y}$ \\
\hline fir1-318R & GCGATGTGCTGTTCGTTCACTTCA & $\ldots$ & $\ldots$ \\
\hline fir2-28F & AGGAGACGTTCGGATCAGCACACA & firl gene, fir2 protein & $\ldots{ }^{\mathrm{y}}$ \\
\hline fir2-287R & AGAGCCTCGACGAGAACGATTCAA & $\ldots$ & $\ldots$ \\
\hline attR-683F & GGTGCAGCAGTATTCGTTGTCGTT & $a t t R$ gene, transcriptional regulator & $\ldots^{\mathrm{z}}$ \\
\hline attR-887R & TGCACATCTCGTCTTCTGCAGTCA & $\ldots$ & $\ldots$ \\
\hline attA-585F & GCCTGGAAGCGCATCAACATCAAT & attA gene, arginino-succinate lyase & $\ldots^{\mathrm{z}}$ \\
\hline attA-879R & TTCTTCTGCGGCATGATCGAGCTA & $\ldots$ & $\ldots$ \\
\hline
\end{tabular}

${ }^{\mathrm{w}}$ ITS $=$ internal transcribed spacer.

${ }^{\mathrm{x}}$ Primers were designed in this research based on the sequences in a previous study.

y Primers were designed in this research based on GenBank no. AJ311775.

${ }^{\text {z }}$ Primers were designed in this research based on GenBank no. AF001836. 
suspensions on YDC (replicated five times, 25 droplets/plate).

Seeds of garden pea (Pisum sativum L.) cvs. Alaska and Green Arrow were surface sterilized by dipping briefly in $70 \%$ ethanol and soaking in $10 \%$ Clorox for $10 \mathrm{~min}$. After rinsing three times with sterile distilled water (SDW) and soaking in SDW for $1 \mathrm{~h}$, seeds were placed aseptically on $1.5 \%$ water agar and incubated for approximately 3 days at $20^{\circ} \mathrm{C}$ until the radicles emerged. Germinated seeds (5 to 10 $\mathrm{mm}$ in radicle length) were soaked in an inoculum of $R$. fascians cells (10 pea seeds per $20 \mathrm{ml}$ of bacterial culture in SAT medium) for $1 \mathrm{~h}$ at room temperature and then transferred into test tubes $(2$ by $15 \mathrm{~cm}$ ) containing $5 \mathrm{ml}$ of Hoagland's agar medium as previously described $(12,15,26)$. Control seeds were immersed in SAT medium. Seedlings were grown in a growth chamber with a 12 -h photoperiod at $18^{\circ} \mathrm{C}$ under fluorescent and incandescent light at 12 klux (Portable Lux Meter, HI 97500; Hanna Instruments, Cluj-Napoka, Romania). The main stem length of seedlings was measured with a digital caliper (ColeParmer, Vernon Hills, IL), and the number of lateral shoots was counted at the level of the cotyledonary node at 14 days post inoculation (dpi) (Fig. 1). Each pea bioassay consisted of 10 seedlings per strain and was repeated at least three times. The degree of virulence was determined based on the percentage of pea seedlings showing fasciation symptoms.

Detection of the fas-1 gene in single colonies of $\boldsymbol{R}$. fascians. Single colonies on YDC were randomly selected to determine whether they carried fas- 1 (and fasR in some samples) using PCR with the primers listed in Table 2. To determine if the proportion of $R$. fascians cells carrying fas- 1 had changed in planta, epiphytic $R$. fascians cells on symptomatic and asymptomatic pea seedlings were isolated at 2 weeks after inoculation by touching the plant surfaces with a sterile bacteriological loop and streaking it onto YDC medium. Cells of $R$. fascians in the inner tissues of infected plants, including galls and lateral shoots, were isolated from $1-\mathrm{cm}$ segments of these tissues that had been surface sterilized by treating them with $10 \%$ Clorox for $2 \mathrm{~min}$ and rinsing three times with a 10 $\mathrm{mM}, \mathrm{pH} 7.4$ phosphate buffer. The absence of viable bacterial cells on the surface after sterilization was confirmed by soaking the segments in the same phosphate buffer for $30 \mathrm{~min}$ and then placing several drops of the buffer solution on YDC. The surfacesterilized segments were finely chopped, suspended in buffer, and then streaked on YDC. Resulting colonies were individually tested for the presence of both the fas-1 and fas $R$ genes by PCR.

Effects of $R$. fascians inoculum concentration and the ratio between cells with and without the fas-1 gene on symptom development in pea seedlings.
To confirm the relationship between the number of fas-1-positive cells and the level of virulence, colonies of fas-1-positive and -negative cells originating from strains Rf59 and Rf-29 were cultured in SAT medium for 3 days. Individual subcultures were serially diluted with SAT medium to prepare inoculum concentrations ranging from 0.0 to $2.5 \times 10^{8} \mathrm{CFU} / \mathrm{ml}$. Pea seedlings were inoculated with each inoculum preparation. The height of the main stem and the number of lateral shoots were determined at 14 dpi. In addition, subcultures derived from fas-1-positive and -negative colonies were mixed in different proportions with a final concentration of $2.5 \times$ $10^{7} \mathrm{CFU} / \mathrm{ml}$. After inoculating pea seedlings with these bacterial mixtures, virulence was evaluated at 14 dpi. Subsequently bacteria were reisolated from the surfaces of the inoculated pea seedlings, and the proportion of fas-1-positive cells among these populations was determined by PCR.

Data analysis. Statistical analyses were performed using SAS software (ver. 9.1;
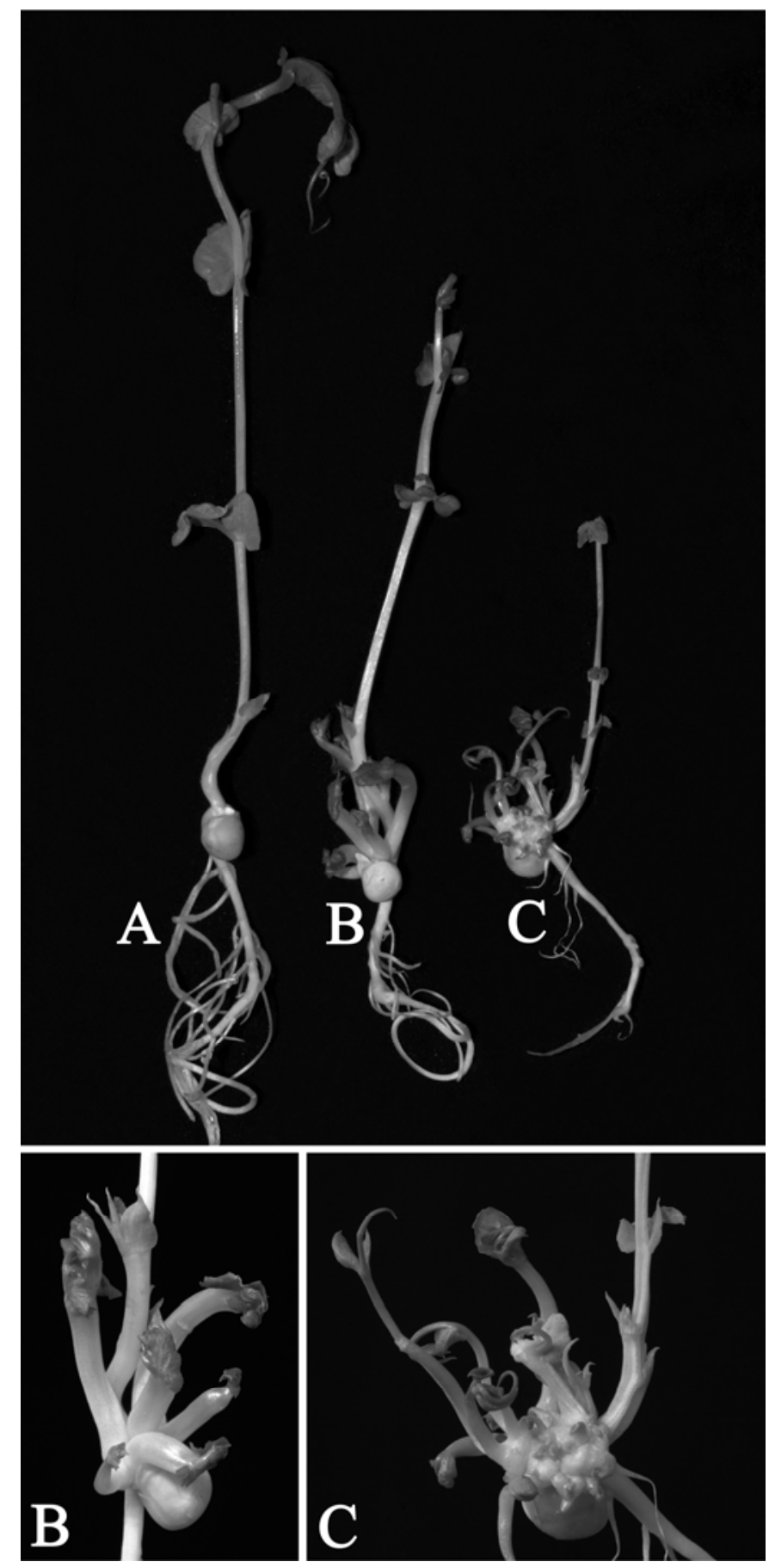

Fig. 1. Fasciation symptoms on seedlings of pea cv. Alaska inoculated with Rhodococcus fascians strain Rf-32. The pictures were taken at 14 days postinoculation. A, Negative control, inoculated with sucrose asparagine thiamine medium; $\mathbf{B}$, multiple shoots at cotyledon node; and $\mathbf{C}$, leafy gall at cotyledon node. 
SAS Institute Inc., Cary, NC). Variation of strains was analyzed using the analysis of variance procedure. Means in multiple comparisons were separated using the Student-Newman-Keuls multiple-range test. The effect of the concentrations of bacterial cells with or without fas- 1 on symptom development was analyzed by paired $t$ test for means. The effect of different ratios of fas-1-positive and -negative cells in inocula on symptom development was analyzed by Tukey's studentized range (highly significant difference) test for means. Pearson correlation coefficient between concentrations of fas-1-positive $R$. fascians cells in mixed inocula and phenotypic characteristics of pea seedlings was determined according to SAS CORR procedure.

\section{RESULTS}

$R$. fascians strains isolated from symptomatic plant samples exhibited a high degree of virulence variability in pea bioassays. Potted flowering crops expressing symptoms of bacterial fasciation were collected from Pennsylvania greenhouses during 1984 to 2005, resulting in $89 R$. fascians strains with different levels of virulence. To understand inconsistencies in virulence testing of the original strains, pea bioassays were conducted again in 2005. As a result, these strains were divided into three groups based on the frequency of symptom development upon inoculation of garden pea seedlings of cvs. Alaska and Green Arrow (StudentNewman-Keuls multiple-range test, $\alpha=$ 0.01 ; Table 1). In all, 31 strains consistently caused fasciation symptoms on $>90 \%$ of seedlings, 27 strains did not symptom development among bacterial

cause any significant disease symptoms, and the remaining 31 strains inconsistently caused symptoms. Multiple shoots or leafy galls (Fig. 1) were observed mostly at the cotyledonary nodes of the seedlings. Most virulent strains $(94.4 \%)$ produced symptoms on both cvs. Alaska and Green Arrow; however, four strains (Rf-29, Rf-40, Rf-66, and Rf-76) produced symptoms only on cv. Alaska. Some strains isolated from the same clinical samples exhibited significantly different levels of virulence (e.g., Rf-21 versus Rf-23, Rf-29 versus Rf30, Rf-53 versus Rf-54, and Rf-72 versus Rf-73). The levels of symptom development caused by strain Rf-29 varied greatly even within a replication $(0,66.7$, and $22.1 \%$, with a mean of $22.2 \%$; Table 1 ). There was no correlation between virulence and the year of isolation (Table 1), the host of origin, or greenhouse location (data not shown). Strain Rf-1 has been stored in PDA since 1984 and still remained highly virulent. Strains that failed to cause disease symptoms on pea also failed to infect several species of potted plants, including the original hosts (data not shown).

The varying occurrence of fas- 1 and fas $R$ in pure cultures of different $R$. fascians strains correlated with their virulence. The high degree of virulence variability among and within certain $R$. fascians strains suggested that their ability to cause fasciation might be unstable and subject to environmental or cultural conditions. A number of genes, such as fas-1, fasR, and vic, have been shown to play essential roles in pathogenicity $(5,25,31)$. We tested the hypothesis that the instability of some of these genes caused the virulence variation. PCR amplification of the

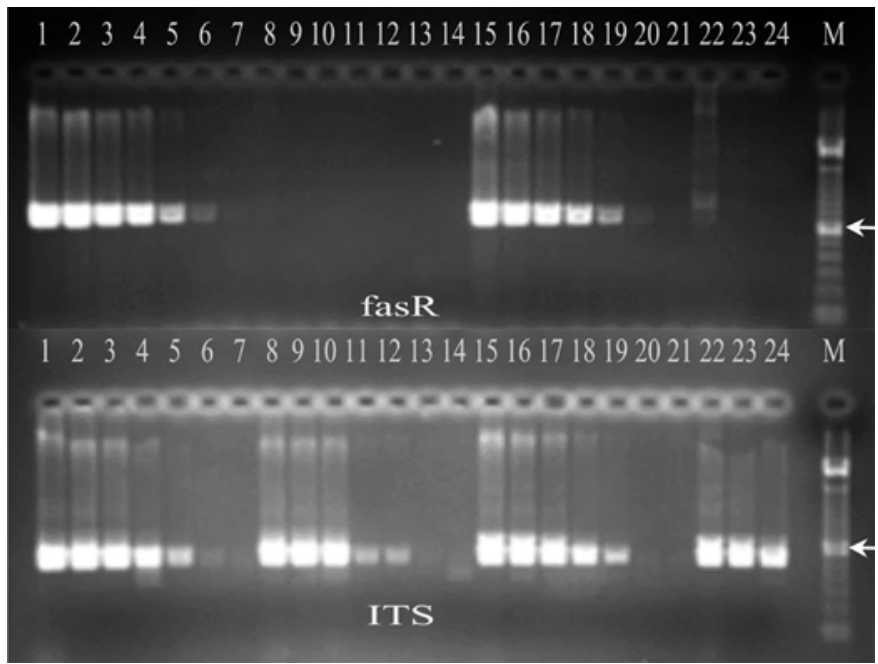

Fig. 2. Polymerase chain reaction amplification of the fas $R$ gene (upper row) and internal transcribed spacer region (lower row) from various Rhodococcus fascians strains. Lanes 1-7, a highly virulent colony from Rf-29 strain. Lanes 8-14, a weakly virulent colony from Rf-29 strain. Lanes 15-21, a highly virulent colony from Rf-32 strain. Lanes $22-24$, an avirulent colony from Rf-9 strain. Lanes 1 , 8,15 , and 22, undiluted genomic DNA extracted from $2.5 \times 10^{8} \mathrm{CFU} / \mathrm{ml}$ of each strain, further diluted to 1:10 (lanes 2, 9, 16, and 23), 1:100 (lanes 3, 10, 17, and 24), 1:1,000 (lanes 4, 11, and 18), 1:10,000 (lanes 5, 12, and 19), 1:100,000 (lanes 6, 13, and 20), and 1:1,000,000 (lanes 7, 14, and 21). M = 100bp DNA ladder (TrackIt; Invitrogen) with the arrow indicating 600-bp band. two plasmid-borne virulence genes fas-1 and fasR (225 bp for fas- 1 and $688 \mathrm{bp}$ for fas $R$ ), showed that all the strains that were able to cause fasciation symptoms in the pea bioassays carried these genes (Fig. 2). However, these genes were also detected in most strains that failed to produce symptoms on pea, although the PCR conditions were the same for all strains (approximately 100 to $200 \mathrm{ng} / \mu \mathrm{l}$ of genomic DNA as template). In the case of the weakly virulent or avirulent strains, only very faint PCR products were obtained (Fig. 2). The possibility that differences in genomic DNA quality were at the basis of the differential amplification of fas- 1 and fasR was ruled out by the successful amplification of the 510-bp ITS region of rRNA genes from all strains. These observations suggested that only a few cells in the cultures of the weakly virulent or avirulent strains carried these virulence genes, which was supported by PCR results with diluted genomic DNA. The target PCR products were successfully amplified from highly virulent strains even after diluting the template DNA to $1: 1,000,000$ (Fig. 2), whereas strains that failed to cause symptoms failed to yield target PCR products when the genomic DNA was diluted 100fold (Table 1; Fig. 2). Amplification of the ITS region with highly diluted genomic DNA, on the other hand, yielded the expected PCR product in all samples regardless of their virulence. Similarly, the chromosomal vicA gene could successfully be amplified in all 27 tested strains representing the three virulence groups (data not shown).

The proportion of fas-1-positive cells within cultures of $R$. fascians strains varied. The results presented above suggested that, within originally pure stock cultures of certain $R$. fascians strains, two distinct cell populations existed: one carrying the fas genes and the other lacking them. The hypothesis that the ratio between these two subpopulations determines the degree of virulence was tested by evaluating the presence of fas- 1 via PCR in randomly selected single colonies subcultured from $31 R$. fascians strains with varying degrees of virulence. Genomic DNAs from 30 to 40 single colonies from each strain were subjected to PCR analysis, which placed the 31 strains into three groups: (i) the 8 strains in group 1 only produced fas-1-positive colonies, (ii) the 19 strains in group 2 were uniformly negative for fas-1, and (iii) the 4 strains in group 3 yielded mixed populations of fas1 -positive and -negative colonies (Table 3 ). In general, symptoms on pea seedlings inoculated with these strains were correlated with the proportion of fas-1-positive colonies. The frequency of fas-1-positive colonies among bacterial populations recovered from inoculated seedlings at 14 dpi was also correlated with disease severity. 
Four strains in group 1 caused disease on all inoculated pea seedlings (subgroup 1a), whereas the remaining four strains caused symptoms on 75.4 to $97.5 \%$ of the inoculated pea seedlings (subgroup 1b). The majority of colonies reisolated from inoculated plants were $f a s-1$ positive $(85.7$ to $100 \%$ ). Fourteen strains in group 2 (subgroup 2a) did not cause any symptoms on pea seedlings, and only fas- 1 -negative colonies were recovered from inoculated seedlings. The remaining four strains of group 2 (subgroup 2b) caused the formation of small lateral shoots on a few pea seedlings, and 2.8 to $18.8 \%$ of the recovered colonies from these seedlings were fas- 1 positive. The strains in group 3 caused symptoms on 20.0 to $52.5 \%$ of the inoculated seedlings, and mixtures of fasl-negative and -positive colonies were recovered from the inoculated seedlings.

Pea seedlings inoculated with cultures of fas-1-positive colonies recovered from plants infected with strains from all three groups caused disease symptoms in 75.2 to $100 \%$ (mean $93.2 \pm 8.1 \%$ ) of inoculated seedlings, whereas those inoculated with cultures of fas-1-negative colonies, regard- less of their origin, did not cause noticeable disease symptoms (data not shown).

Severity of disease symptoms was dependent upon the number of fas-1positive cells in the inoculum. The results described above show that the presence of fas- 1 is essential for symptom development, confirming the observations of Stange and co-workers (23). Our data also suggest that disease severity is related to the number of fas-1-postive cells in the inoculum. To determine the minimum number of fas-1-positive cells required for symptom development, we inoculated

Table 3. Grouping of Rhodococcus fascians strains based on the proportion of fas-1-positive cells

\begin{tabular}{|c|c|c|c|}
\hline Group, subgroup, strain ${ }^{w}$ & Before inoculation $(\%)^{x}$ & Symptom development $(\%)^{y}$ & After inoculation $(\%)^{\mathrm{x}, \mathrm{z}}$ \\
\hline \multicolumn{4}{|l|}{ Group 1} \\
\hline \multicolumn{4}{|l|}{$1 \mathrm{a}$} \\
\hline Rf-01, Rf-32, Rf-36 & $100.0 \pm 0.0$ & $100.0 \pm 0.0$ & $100.0 \pm 0.0$ \\
\hline Rf-27 & $100.0 \pm 0.0$ & $100.0 \pm 0.0$ & $87.5 \pm 7.4$ \\
\hline \multicolumn{4}{|l|}{$1 \mathrm{~b}$} \\
\hline Rf-51 & $100.0 \pm 0.0$ & $75.4 \pm 8.0$ & $94.4 \pm 3.6$ \\
\hline Rf-56 & $100.0 \pm 0.0$ & $97.5 \pm 1.6$ & $93.8 \pm 7.2$ \\
\hline Rf-59 & $100.0 \pm 0.0$ & $87.5 \pm 4.9$ & $97.2 \pm 2.3$ \\
\hline Rf-70 & $100.0 \pm 0.0$ & $87.5 \pm 8.3$ & $85.7 \pm 5.1$ \\
\hline \multicolumn{4}{|l|}{ Group 2} \\
\hline \multicolumn{4}{|l|}{$2 \mathrm{a}$} \\
\hline $\begin{array}{l}\text { Rf-08, Rf-09, Rf-14, Rf-37, Rf-38, Rf-44, Rf-60, Rf-63, Rf-67, } \\
\text { Rf-71, Rf-74, Rf-75, Rf-80, Rf-81 }\end{array}$ & $0.0 \pm 0.0$ & $0.0 \pm 0.0$ & $0.0 \pm 0.0$ \\
\hline \multicolumn{4}{|l|}{$2 b$} \\
\hline Rf-21 & $0.0 \pm 0.0$ & $5.2 \pm 4.5$ & $2.8 \pm 2.8$ \\
\hline Rf-26 & $0.0 \pm 0.0$ & $3.6 \pm 3.5$ & $3.1 \pm 3.1$ \\
\hline Rf-40 & $0.0 \pm 0.0$ & $7.2 \pm 2.0$ & $2.3 \pm 2.3$ \\
\hline Rf-66 & $0.0 \pm 0.0$ & $10.3 \pm 3.5$ & $18.8 \pm 5.5$ \\
\hline \multicolumn{4}{|l|}{ Group 3} \\
\hline Rf-29 & $75.0 \pm 5.8$ & $22.2 \pm 7.3$ & $37.5 \pm 12.5$ \\
\hline Rf-41 & $10.5 \pm 4.1$ & $20.0 \pm 7.6$ & $15.4 \pm 6.2$ \\
\hline Rf-53 & $75.0 \pm 6.4$ & $52.5 \pm 3.1$ & $41.7 \pm 8.3$ \\
\hline Rf-72 & $25.0 \pm 6.5$ & $51.5 \pm 5.1$ & $34.4 \pm 6.6$ \\
\hline Rf-79 & $11.6 \pm 5.3$ & $26.5 \pm 8.1$ & $17.5 \pm 5.4$ \\
\hline
\end{tabular}

${ }^{\mathrm{w}}$ Strains in groups 1 and 2 were further divided into two subgroups based on the degree of symptom development.

${ }^{\mathrm{x}}$ Fas-1 positive colonies before or after inoculation. Percentages (means \pm standard error [SE]) of fas-1-positive colonies for each strain were determined before and after pea inoculation by analyzing randomly taken single colonies growing on yeast-dextrose-calcium carbonate (YDC) medium by polymerase chain reaction (PCR). Up to 40 colonies per strain were screened. PCR was performed with approximately $1 \mathrm{ng}$ of bacterial genomic DNA as a template.

y Symptom development (means \pm SE) reflects the percentage of seedlings of cv. Alaska showing fasciation symptoms at 14 days post inoculation. Three independent inoculation assays (10 pea seedlings for each assay) were performed.

${ }^{\mathrm{z}}$ Bacterial cells were reisolated from the cotyledonary node of inoculated pea seedlings by touching with a loop and streaking on YDC.

Table 4. Number of fas-1-positive cells affects symptom development

\begin{tabular}{|c|c|c|c|c|c|c|}
\hline \multirow[b]{3}{*}{ Strain $(\mathrm{CFU} / \mathrm{ml})^{\mathrm{z}}$} & \multicolumn{6}{|c|}{ Phenotypic characteristics of pea seedlings ${ }^{y}$} \\
\hline & \multicolumn{3}{|c|}{ Main stem length (mm) } & \multicolumn{3}{|c|}{ Number of lateral shoots } \\
\hline & fas $-1(+)$ & fas $-1(-)$ & $P$ value & fas $-1(+)$ & fas-1 (-) & $P$ value \\
\hline \multicolumn{7}{|l|}{ Rf-29 } \\
\hline $2.5 \times 10^{4}$ & $154.3 \pm 5.4$ & $166.4 \pm 8.1$ & 0.052 & $2.4 \pm 0.4$ & $0.0 \pm 0.0$ & 0.0008 \\
\hline $2.5 \times 10^{5}$ & $124.1 \pm 9.4$ & $169.8 \pm 6.7$ & 0.019 & $4.3 \pm 0.4$ & $0.0 \pm 0.0$ & $<0.0001$ \\
\hline $2.5 \times 10^{6}$ & $107.8 \pm 10.9$ & $166.3 \pm 6.5$ & 0.003 & $5.6 \pm 0.5$ & $0.0 \pm 0.0$ & $<0.0001$ \\
\hline $2.5 \times 10^{7}$ & $98.6 \pm 7.6$ & $163.1 \pm 5.1$ & $<0.0001$ & $7.2 \pm 0.6$ & $0.0 \pm 0.0$ & $<0.0001$ \\
\hline $2.5 \times 10^{8}$ & $74.0 \pm 4.4$ & $167.3 \pm 4.7$ & $<0.0001$ & $8.4 \pm 0.6$ & $0.0 \pm 0.0$ & $<0.0001$ \\
\hline \multicolumn{7}{|l|}{ Rf-59 } \\
\hline $2.5 \times 10^{4}$ & $157.0 \pm 6.8$ & $166.2 \pm 5.4$ & 0.059 & $3.1 \pm 0.4$ & $0.0 \pm 0.0$ & 0.0002 \\
\hline $2.5 \times 10^{5}$ & $132.4 \pm 12.8$ & $167.3 \pm 6.2$ & 0.007 & $4.2 \pm 0.4$ & $0.0 \pm 0.0$ & $<0.0001$ \\
\hline $2.5 \times 10^{6}$ & $120.8 \pm 8.9$ & $167.1 \pm 6.4$ & 0.0008 & $6.4 \pm 0.4$ & $0.0 \pm 0.0$ & $<0.0001$ \\
\hline $2.5 \times 10^{7}$ & $94.5 \pm 7.1$ & $165.9 \pm 5.5$ & $<0.0001$ & $7.1 \pm 0.5$ & $0.0 \pm 0.0$ & $<0.0001$ \\
\hline $2.5 \times 10^{8}$ & $67.9 \pm 5.7$ & $167.2 \pm 4.8$ & $<0.0001$ & $8.6 \pm 0.4$ & $0.0 \pm 0.0$ & $<0.0001$ \\
\hline
\end{tabular}

y Phenotypic characteristics of pea seedlings (cv. Alaska) inoculated with Rhodococcus fascians were recorded at 14 days post inoculation. Values in each pair are means \pm standard error. Analysis by Paired $t$ test for means was conducted using SAS. Three independent inoculation assays (10 pea seedlings each) were performed. Sucrose asparagine thiamine medium was used as a negative control. No significant differences in lateral shoots formation or main stem lengths were observed for the concentrations from 0.0 to $2.5 \times 10^{3} \mathrm{CFU} / \mathrm{ml}$. Cultures of fas-1-positive (+) or -negative (-) cells were prepared by selecting single colonies from $R$. fascians strains Rf-29 and Rf-59.

${ }^{\mathrm{z}}$ Strain and inoculum concentration. 
seedlings of cv. Alaska (10 plants for each treatment) with varying concentrations of fas-1-positive cells derived from two $R$. fascians strains, Rf-59 (group 1b) and Rf29 (group 3) (Table 4). As negative controls, inocula were prepared starting from fas-1-negative cells derived from Rf-59 and Rf-29. In pea seedlings inoculated with fas-1-positive cells of Rf-29, the first noticeable disease symptom, the formation of small lateral shoots, was observed at 2.5 $\times 10^{4} \mathrm{CFU} / \mathrm{ml}$ (paired $t$ test, $P=0.0008$ ). The suppression of seedling growth was observed at $2.5 \times 10^{5} \mathrm{CFU} / \mathrm{ml}$ (paired $t$ test, $P=0.019)$. As the concentration of fas-1-positive cells increased, the severity of disease symptoms gradually increased. Starting at $2.5 \times 10^{6} \mathrm{CFU} / \mathrm{ml}$ or higher, at least $50 \%$ of the seedlings produced galls at 14 dpi. The results obtained from the seedlings inoculated with fas-1-positive cells derived from Rf-59 were comparable with those with Rf-29. All inocula prepared from fas-1-negative cells (up to 2.5 $\times 10^{8} \mathrm{CFU} / \mathrm{ml}$ ) or SAT medium failed to cause fasciation symptoms (Table 4 ).
The degree of disease symptoms was correlated with the proportion of fas1 -positive cells in mixed inocula. Pea seedlings inoculated with mixtures of fas-1-positive and -negative cells derived from both Rf-29 and Rf-59 exhibited a strong correlation (Pearson's $r \geq 0.9205$ ) between the proportion of fas-1-positive cells and disease severity (Table 5). With both strains, lateral shoot formation was induced when $5 \%$ of the total population carried fas-1. Growth suppression and leafy gall formation, on the other hand, required $25 \%$ or more fas-1-positive cells.

To determine if fas-1-positive and -negative cells preferentially colonize different parts of pea seedlings when inoculated as mixed cultures, more than 200 bacterial colonies, isolated from both the surface and the inner tissues (about 20\% of the total) of inoculated seedlings, were screened by PCR. Only cells that were positive for fas-1 were isolated from internal parts of the leafy galls and lateral shoots, whereas both fas-1-positive and -negative cells were found on the surface (data not shown).

The whole virulence plasmid appears to be lost among fas-1-negative cells. The absence of the fas genes in certain strains might have been caused by the loss of the whole virulence plasmid or deletion of just the fas operon. To determine which is the case, the presence of four additional genes on the plasmid (attA, attR, firl, and fir2), which are located at different positions on the plasmid, was determined by PCR. In all cases tested, simultaneous losses of all four genes were observed in fas-1-negative avirulent strains and avirulent subcultures from mixed strains (Table 6), suggesting that decreased virulence was due to loss of the entire plasmid.

\section{DISCUSSION}

Earlier studies showed that the fas-1 gene, involved in the synthesis of a cytokinin-like signal molecule, and the fas $R$ gene, regulating the expression of fas-1, are absolutely required for the development of fasciation symptoms $(4,5,23,25)$.

Table 5. Effect of fas-1-positive cells in mixed inocula on symptom development of the proportion

\begin{tabular}{|c|c|c|c|c|c|c|}
\hline \multirow[b]{3}{*}{ Inoculum (\%) (+:-) $)^{\mathrm{y}}$} & \multicolumn{6}{|c|}{ Phenotypic characteristics of pea seedlings ${ }^{x}$} \\
\hline & \multicolumn{2}{|c|}{ Main stem length (mm) } & \multicolumn{2}{|c|}{ Number of lateral shoots } & \multicolumn{2}{|c|}{ Seedlings with galls $(\%)$} \\
\hline & Rf-29 & Rf-59 & Rf-29 & Rf-59 & Rf-29 & Rf-59 \\
\hline 0.0:0.0 & 166.0 & 166.5 & 0.0 & 0.0 & 0.0 & 0.0 \\
\hline $0.0: 100.0$ & 159.0 & 162.4 & 0.0 & 0.0 & 0.0 & 0.0 \\
\hline $0.1: 99.9$ & 156.5 & 165.5 & 0.0 & 0.0 & 0.0 & 0.0 \\
\hline $0.5: 99.5$ & 157.3 & 157.8 & 0.2 & 0.6 & 0.0 & 0.0 \\
\hline $5.0: 95.0$ & 151.0 & 154.1 & $2.1 * * *$ & $2.1 * * *$ & 0.0 & 20.0 \\
\hline $15.0: 85.0$ & 150.8 & 144.5 & $4.1 * * *$ & $4.0 * * *$ & 0.0 & 20.0 \\
\hline $25.0: 75.0$ & $139.5 * * *$ & $125.5 * * *$ & $4.6 * * *$ & $5.1 * * *$ & 10.0 & $40.0 * * *$ \\
\hline $50.0: 50.0$ & $136.8 * * *$ & $113.8 * * *$ & $4.6 * * *$ & $5.4^{* * *}$ & 20.0 & $40.0 * * *$ \\
\hline $75.0: 25.0$ & $132.7 * * *$ & $101.9 * * *$ & $5.4 * * *$ & $5.6^{* * *}$ & $30.0 * * *$ & $50.0 * * *$ \\
\hline $85.0: 15.0$ & $123.2 * * *$ & $102.8 * * *$ & $6.0 * * *$ & $6.1^{* * *}$ & $40.0^{* * *}$ & $60.0 * * *$ \\
\hline $95.0: 5.0$ & $100.8 * * *$ & $95.8 * * *$ & $7.0 * * *$ & $6.1 * * *$ & $30.0 * * *$ & $70.0 * * *$ \\
\hline 100.0:0.0 & $91.1 * * *$ & $93.6^{* * *}$ & $6.9 * * *$ & $7.2 * * *$ & $40.0^{* * *} *$ & $60.0 * * *$ \\
\hline Pearson ${ }^{\mathrm{Z}}$ & -0.9929 & -0.9712 & 0.9996 & 0.9205 & 0.9659 & 0.9519 \\
\hline
\end{tabular}

${ }^{\mathrm{x}}$ Fas-1-positive and -negative cells derived from Rf-29 and Rf-59 were mixed in different proportions; 0.0:0.0 = control. The total number of cells in each inoculum mix was $2.5 \times 10^{7} \mathrm{CFU} / \mathrm{ml}$. Numbers marked with *** are significantly different from controls according to Tukey's Studentized Range Test $(\alpha=$ $0.05)$, SAS analysis of variance procedure.

y Composition of inoculum, ratio of fas-1-positive (+) to fas-1-negative (-). Phenotypic characteristics of pea seedlings (cv. Alaska) inoculated with Rhodococcus fascians were recorded at 14 days post inoculation. Sucrose asparagine thiamine medium was used as a negative control. Three independent inoculation assays (10 pea seedlings each) were performed.

${ }^{\mathrm{z}}$ Pearson correlation coefficient between the proportion of fas-1-positive cells in mixed inocula and the phenotypic characteristics of inoculated pea seedlings according to the SAS CORR procedure.

Table 6. Presence of plasmid genes in virulent and avirulent strains of Rhodococcus fascians

\begin{tabular}{|c|c|c|c|c|c|c|c|c|c|}
\hline \multirow[b]{3}{*}{ Strain no. ${ }^{y}$} & \multirow[b]{3}{*}{ Symptoms $^{z}$} & \multicolumn{8}{|c|}{ PCR markers ${ }^{x}$} \\
\hline & & \multicolumn{2}{|c|}{ Chromosome } & \multicolumn{6}{|c|}{ Plasmid } \\
\hline & & 16S rDNA & $\operatorname{vic} A$ & fas -1 & fas $R$ & fir 1 & fir 2 & attR & attA \\
\hline Rf-59v & + & + & + & + & + & + & + & + & + \\
\hline Rf-59a & - & + & + & - & - & - & - & - & - \\
\hline Rf-29v & + & + & + & + & + & + & + & + & + \\
\hline Rf-29a & - & + & + & - & - & - & - & - & - \\
\hline Rf-01 & + & + & + & + & + & + & + & + & + \\
\hline Rf-32 & + & + & + & + & + & + & + & + & + \\
\hline Rf-08 & - & + & + & - & - & - & - & - & - \\
\hline Rf-14 & - & + & + & - & - & - & - & - & - \\
\hline
\end{tabular}

$\mathrm{x}$ Presence of the target genes was determined by polymerase chain reaction $(\mathrm{PCR}$; at least three replications for each strain); $+=$ positive and $-=$ negative.

y Subcultures derived from Rf-29 and Rf-59 were tested; $\mathrm{v}=$ virulent and $\mathrm{a}=$ avirulent.

${ }^{z}$ Symptom development reflects the development of fasciation symptoms on pea seedlings (cv. Alaska) at 14 days post inoculation. Three independent inoculation assays (10 seedlings for each assay) were performed. 
The 89 Pennsylvania clinical $R$. fascians strains obtained from symptomatic plants showed a high degree of virulence variability on garden pea seedlings (Table 1). PCR-based surveys revealed that many of these strains consisted of different proportions of fas-1-positive cells and that their virulence correlated with the proportion of fas-1-positive cells (Tables 1, 3, and 5). The apparent instability of the fas genes, as well as the whole plasmid carrying these genes (Table 6), resulted in mixed bacterial subpopulations, consisting of those that carry fas- 1 and those lacking the gene; this led to virulence variation and might explain the frequent isolation of nonpathogenic strains from symptomatic plants $(11,12,21,28)$. Because natural populations are likely to consist of both cell types, isolation of single colonies for purification and storage may lead to preservation of nonpathogenic strains and, therefore, is not recommended.

The ability of some strains, originally classified as weakly virulent or nonpathogenic, to cause a high incidence of disease on pea seedlings when fas-1-postive subcultures of these strains were used for infection (Tables 1 and 3) suggests that most strains isolated from symptomatic plants have the potential to be highly virulent as long as they carry the fas- 1 gene. Manipulation or culturing seems to change the number of cells carrying fas-1. Inoculation of the pea seedlings helped to differentiate virulent and avirulent cells. If at least a few plants inoculated with "nonpathogenic" strain (Table 3, group 2a) showed light fasciation symptoms, there was more likelihood to find fas-1-positive cells. However, for $R$. fascians, the host does not necessarily select out virulent cells from a mixture because $R$. fascians is a well-adapted epiphyte that can grow well on the surface of plants without the need to cause fasciation or galls (3).

The conditions or factors that control the stability of the virulence plasmid in $R$. fascians remain to be determined. We could not relate virulence to the year of isolation, origin, or host of the tested strains. In other pathogenic species, including Shigella flexneri, Escherichia coli, Agrobacterium tumefaciens, Pseudomonas syringae, and $R$. equi $(2,22,24,33,34)$, changing growth or environmental conditions (e.g., temperature and nutrition) can potentially promote the loss or instability of virulence plasmids. In nature, when conditions are such that the presence of plasmids does not confer any selective advantage, it may be beneficial for bacteria to lose their plasmids or to strongly reduce the number of plasmid-carrying cells in the population so that valuable resources are not directed toward plasmid maintenance. When conditions change and the presence of the plasmids becomes advantageous, the proportion of cells carrying the plasmids will increase by selective reproduction of plasmid-carrying cells or by horizontal transfer of the plasmids throughout the population (2). Bacterial genes conferring antibiotic resistance are such examples.

Whereas host surfaces, surrounding areas (e.g., soil and water), or nutrient-rich media might be conditions in which fas- 1 does not confer any selective advantage to $R$. fascians, the endophytic environment might favor the presence of the virulence plasmid. In support of this hypothesis, we recovered only fas-1-positive cells from the inner tissues of symptomatic pea seedlings inoculated with mixtures of fas-1positive and -negative cells, while the epiphytic population consisted of both cell types. However, in a previous report, the nonpathogenic plasmid-free derivative D188-5 of the pathogenic $R$. fascians strain D188 could epiphytically colonize tobacco and Arabidopsis very well but was much less efficient in penetrating into the plant tissues (3). Therefore, we cannot rule out the possibility that some unknown penetration determinants are also encoded by the linear plasmid which would contribute to the differential occurrence of fas1-positive and -negative cells inside of the plant. The fas locus, which is needed for cytokinin production $(6,9)$, changes the hormone balance in the plant in a manner that creates a specific niche for $R$. fascians.

A practical implication of virulence instability among clinical isolates is that care should be taken when the pathogenicity of $R$. fascians strains isolated from plants is assessed. Because it is likely that the natural populations consist of mixtures of fas1-positive and -negative cells, virulence evaluation should not be based on pure cultures starting from a single colony. Instead, pea bioassays with cultures derived from randomly pooled colonies are a useful approach to estimate "overall virulence" of $R$. fascians strains isolated from field samples, whereas infection assays with cultures derived from a single fas-1positive colony (identified by PCR) can be used to determine the "maximum virulence potential" of individual strains. A better understanding of the conditions or factors affecting the proportion of fas-carrying cells will help design consistent virulence evaluation assays for field isolates and might lead to novel control methods against $R$. fascians by stimulating the loss of the virulence genes.

\section{ACKNOWLEDGMENTS}

This project was supported by grants from the Pennsylvania Department of Agriculture (ME442316 and ME 445580). We thank the plant inspectors and technicians of the Pennsylvania Department of Agriculture for collecting plant samples used in this study.

\section{LITERATURE CITED}

1. Bradbury, J. F. 1986. Rhodococcus Zopf. 1891. Pages 185-187 in: Guide to Plant Pathogenic Bacteria. J. F. Bradbury, ed. CAB International Mycological Institute, Slough, UK.

2. Coplin, D. L. 1989. Plasmids and their role in the evolution of plant pathogenic bacteria Annu. Rev. Phytopathol. 27:187-212.

3. Cornelis, K., Ritsema, T., Nijsse, J., Holsters, M., Goethals, K., and Jaziri, M. 2001. The plant pathogen Rhodococcus fascians colonizes the exterior and interior of the aerial parts of plants. Mol. Plant-Microbe Interact. 14:599-608

4. Crespi, M., Messens, E., Caplan, A. B., Van Montagu, M., and Desomer, J. 1992. Fasciation induction by the phytopathogen Rhodococcus fascians depends upon a linear plasmid encoding a cytokinin synthase gene. EMBO J. 11:795-804.

5. Crespi, M., Vereecke, D., Temmerman, W., Van Montagu, M., and Desomer, J. 1994. The fas operon of Rhodococcus fascians encodes new genes required for efficient fasciation of host plants. J. Bacteriol. 176:2492-2501.

6. Depuydt, S., Dolezal, K., Van Lijsebettens, M., Morits, T., Holsters, M., and Vereecke, D. 2008. Modulation of the hormone setting by Rhodococcus fascians results in ectopic KNOX activation in Arabidopsis. Plant Physiol. 146:1267-1281.

7. Eason, R. J., Jameson, P. E., and Bannister, P. 1995. Virulence assessment of Rhodococcus fascians strains on pea cultivars. Plant Pathol. 44:141-147.

8. Eason, R. J., Morris, R. O., and Jameson, P. E. 1996. The relationship between virulence and cytokinin production by Rhodococcus fascians (Tilford 1936) Goodfellow 1984. Plant Pathol. 45:323-331.

9. Goethals, K., Vereecke, D., Jaziri, M., Van Montagu, M., and Holsters, M. 2001. Leafy gall formation by Rhodococcus fascians. Annu. Rev. Phytopathol. 39:27-52.

10. Goodfellow, M. 1984. Reclassification of Corynebacterium fascians (Tilford) Dowson in the genus Rhodococcus, as Rhodococcus fascians comb. nov. Syst. Appl. Microbiol. 115:479-489.

11. Hu, F. P., Fletcher, M. J., Watson, D. R. W., Clark, R. G., and Young, J. M. 1992. Identification of Rhodococcus fascians (Tilford 1936) Goodfellow 1984. J. Phytopathol. 136:37-45.

12. Kim, S. H., and Woodward, W. A. 1985 Evaluation of pea cultivars for use in the bioassay for the pathogenicity of Corynebacterium fascians. (Abstr.) Phytopathology S75:1379.

13. Lacey, M. S. 1936. Studies in bacteriosis. XXII. The isolation of a bacterium associated with "fasciation" of sweet peas, "cauliflower" strawberry plants and "leafy gall" of various plants. Ann. Appl. Biol. 23:302-310.

14. Lacey, M. S. 1939. Studies in bacteriosis. XXIV. Studies on a bacterium associated with leafy galls, fasciations and "cauliflower" disease of various plants. Part III. Further isolation, inoculation experiments and cultural studies. Ann. Appl. Biol. 26:262-278.

15. Lawson, E. N., Gantotti, B. V., and Starr, M. P. 1982. A 78-megadalton plasmid occurs in avirulent strains as well as virulent strains of Corynebacterium fascians. Curr. Microbiol. 7:327-332.

16. Manes, C.-L. de O., Van Montagu, M., Prinsen, E., Goethals, K., and Holsters, M 2001. De novo cortical cell division triggered by the phytopathogen Rhodococcus fascians in tobacco. Mol. Plant-Microbe Interact. 14:189195.

17. Martin-Laurent, F., Philippot, L., Hallet, S., Chaussod, R., Germon, J. C., Soulas, G., and Catroux, G. 2001. DNA extraction from soils: Old bias for new microbial diversity analysis methods. Appl. Environ. Microbiol. 67:23542359.

18. Miller, H. J., Janse, J. D., Kamerman, W., and Muller, P. J. 1980. Recent observations of leafy gall in Liliaceae and some other families. Neth. J. Plant Pathol. 86:55-68.

19. Nikolaeva E. V., Park S., Kang S., Olson T. N., 
and Kim, S. 2007. Recurrence of bacterial fasciation on flowering potted plants in Pennsylvania. (Abstr.) Phytopathology 97:S84.

20. Oduro, K. A 1975. Factors affecting epidemiology of bacterial fasciation of Chrysanthemum maximum. Phytopathology 65:719-721.

21. Putnam, M. L., and Miller, M. 2007. Rhodococcus fascians in Herbaceous Perennials. Plant Dis. 91:1064-1076.

22. Scuch, R., and Maurelli, A. Virulence plasmid instability in Shigella flexneri $2 \mathrm{a}$ is induced by virulence gene expression. Infect. Immun. 65:3686-3692.

23. Stange, R. R., Jeffares, D., Young, C., Scott, D. B., Eason, J. R., and Jameson, P. E. 1996. PCR amplification of the fas-1 gene for the detection of virulent strains of Rhodococcus fascians. Plant Pathol. 45:407-417.

24. Takai, S., Watanabe, Y., Ikeda, T., Ozava, T., Matsukura, S., Tamada, Y., Tsubaki, S., and Sekizaki, T. 1993. Virulence-associated plasmids in Rhodococcus equi. J. Clin. Microbiol. 31:1726-1729.

25. Temmerman, W., Vereecke, D., Dreesen, R.,
Van Montagu, M., Holsters, M., and Goethals, K. 2000. Leafy gall formation is controlled by fasR, an AraC-type regulatory gene in Rhodococcus fascians. J. Bacteriol. 182:5832-5840.

26. Thimann, K. V., and Sachs, T. 1966. The role of cytokinins in the "fasciation" disease caused by Corynebacterium fascians. Am. J. Bot. 53:731-739.

27. Tilford, P. E. 1936. Fasciation of sweet pea caused by Phytomonas fascians n. sp. J. Agric. Res. 53:383-394.

28. Ulrychova, M., and Petru, E. 1983. Isolation of some strains of Corynebacterium fascians (Tilford) Dowson in Czechoslovakia. Biol. Plant. 25:63-67.

29. Vandeputte, O., Oden, S., Mol, A., Vereecke, D., Goethals, K., Jaziri, M., and Prinsen, E. 2005. Biosynthesis of auxin by the grampositive phytopathogen Rhodococcus fascians is controlled by compounds specific to infected plant tissues. Appl. Environ. Microbiol. 71:1169-1177.

30. Vereecke, D., Burssen S., Simon-Mateo, C., Inze, D., Van Montagu, M., Goethals, K., and
Jaziri, M. 2000. The Rhodococcus fasciansplant interaction: Morphological traits and biotechnological applications. Planta 210:241251.

31. Vereecke, D., Cornelis, K., Temmerman, W. Jaziri, M., Van Montagu, M., Holsters, M., and Goethals, K. 2002. Chromosomal locus that af fects pathogenicity of Rhodococcus fascians. J. Bacteriol. 184:1112-1120.

32. Vereecke, D., Temmerman, W., Jaziri, M Holsters, M., and Goethals, K. 2003. Toward an understanding of the Rhodococcus fascians-plant interaction. Pages 53-79 in: PlantMicrobe Interaction, vol. 6. G. Stacy and N Kech, eds. American Phytopathological Society, St. Paul, MN.

33. Vivian, A., Murillo, J., and Jackson, R.W 2001. The roles of plasmids in phytopathogenic bacteria: mobile arsenals? Microbiology 147:763-780.

34. Watson, B., Currier, T. C., Gordon, M. P. Chilton, M., and Nester, E. W. 1975. Plasmid required for virulence of Agrobacterium tumefaciens. J. Bacteriol. 123:255-264. 